\title{
TRANSLOCATIONS IN MAIZE INVOLVING CHROMOSOME 9
}

\author{
E. G. ANDERSON \\ California Institute of Technology, Pasadena, California \\ Received February 4, I938 \\ INTRODUCTION
}

HE $C w x$ linkage group associated with chromosome 9 was one of
the first to be established in maize. This was largely due to the excellence of the two genes $C$ and $w x$ as working tools. EMERSON, BEADLE and FRASER (I935) list 28 genes in this group. Nearly all of these are to the left of $w x$ or within Io or I 5 units to the right. MCCLintock (I930, i93 I), Creighton and MCCuntock (I93 I), Creighton (I934) and BuRnHAM (1930, 1934a, b) have shown that the gene $y g_{2}$ is near the end of the short arm of chromosome 9 and $w x$ nearer the spindle attachment but still on the short arm. Virescent $t_{1}\left(v_{1}\right)$ is probably on the long arm not far from the spindle attachment (BEADLE I932, BuRnHAM I934b). The greater portion of the long arm is conspicuous by its lack of definitely known genes. This lack of known genes may be largely due to the difficulty of detecting genes in the distal part of the long arm by means of ordinary linkage tests with such genes as $C$, sh and $w x$. Or it may be that such regions are redundant sections of chromosome materials which are also represented elsewhere in the chromosome complement.

Chromosomal interchanges or reciprocal translocations are excellent tools for the exploration of portions of chromosomes where no known genes are available. For most cases it is only necessary to cross any new or unplaced gene with the appropriate translocation stock, backcross with the new gene if recessive or with a normal stock if dominant. Classification of the gene character under consideration and semisterility will give a direct linkage test with a known point on the chromosome.

The chromosome 9 translocations studied by the writer have all been on the long arm, mostly in the region beyond the present known genes. They do not add appreciably to our knowledge of the region covered by the present linkage maps, but do furnish excellent means for the placement and mapping of genes in the extensive region of the long arm where no genes are as yet available.

PREVIOUS DATA ON TRANSLOCATIONS INVOLVING CHROMOSOME 9

T8-9a (Burnham i930, I934b; MCClintock i930, i93 I; Creighton and McClintock I93I; BEADLE I932). The interchange on chromosome 9 on the long arm .4 of distance out from spindle attachment. Linkage order $C$-w $x$ - $T$ with 13.7 percent of crossing over with waxy. 
T5-9a (BURnham 1934a). Interchange in proximal part of the short arm of chromosome 9. Linkage order $s h$-wx- $\mathrm{T}$ with about two percent of crossing over with waxy. Much non-homologous pairing and much suppression of crossing over.

T6-9a (ANDERSON 1934, MCCLINTOCK 1934). Interchange about one-third the way out on the long arm of chromosome 9 . Linkage order $C-w x-T$ with I I.6 percent of crossing over with waxy.

\section{TRANSLOCATIONS INCLUDED IN THE PRESENT STUDY}

In the present paper, data are presented on the following translocations which are included in the writer's published list (ANDERson, I935); T I-9a, b, c, 2-9a, b , 3-9a, b, 4-9a, b, 6-9a, b, and 8-9b. In addition two others are included which will be designated $\mathrm{T}_{3}-9 \mathrm{c}$ and $\mathrm{T}_{9}-\mathrm{I} O \mathrm{~b}$. Both were from the writer's X-rayed material (ANDERSon I935, Lot I, sixty minute treatment, and Lot 2, fifty minute treatment, respectively). The chromosomes involved were determined by diakinesis observations of intercrosses with known translocations. $\mathrm{T}_{3}-9 \mathrm{c}$ gave two rings of four in crosses with $\mathrm{T}_{\mathrm{I}-2 \mathrm{a}}$, $\mathrm{T}_{\mathrm{I}-7 \mathrm{a}, \mathrm{T}} 4-8 \mathrm{a}, \mathrm{T}_{5-7 \mathrm{a}}$ and $\mathrm{T}_{4-5} \mathrm{a}$, and a ring of six with $\mathrm{T} 8-9 \mathrm{a}$ and $\mathrm{T}$ 2-3a. $\mathrm{T}$ 9-Iob gave two rings of four with $\mathrm{T}_{\mathrm{I}-7 \mathrm{a}, \mathrm{T}} 4-8 \mathrm{a}, \mathrm{T}_{4}-5 \mathrm{a}$, and $\mathrm{T}$ 2-3a, and a ring of six with $\mathrm{T}_{3-9 \mathrm{a}}$ and $\mathrm{T}_{3}$-Ioa. These determinations of chromosomes involved have been checked by cytological observation at mid-prophase and by linkage tests.

No data are presented on $\mathrm{T} 9$-Ioa as this translocation involves problems connected with the survival of unbalanced gametes and will be reported as a separate paper.

\section{LINKAGE DATA}

Since most of the linkage tests with genes from chromosome 9 were made involving the same genes in the same linkage order, the summarized data have been combined in a few tables. The individual cultures have been fairly consistent with the exception of $\mathrm{T}$ 4-9a and $\mathrm{T}$ 6-ga which are presented in more detail. Except for $T$ 6-ga, backcrosses using the $F_{1}$ as male or female have given similar results and are combined in the tables. The arrangement of data in the tables is like that in the linkage summary of EMERson, BEADLE and Fraser (I935).

Backcross data involving various translocations with the two genes $C$ and $w x$ are presented in table I. Data similarly involving the three genes $C$, sh and $w x$ are presented in table 2 . Additional data involving only $w x$ are given in table 3 while table 4 gives data involving the genes $C$ and $s h$ with $T$ 8-9b. In several of the backcross cultures there were large discrepancies between several of the contrary classes, due partly to lower viability of $s h$ and $w x$, but chiefly to the presence of $y g_{2}$ and one other weak 
TABLE I

Backcross progenies from combinations $\frac{C+T}{+w x+}$.

\begin{tabular}{|c|c|c|c|c|c|c|c|c|c|c|c|c|}
\hline \multirow{2}{*}{$\mathrm{c}$} & \multirow{2}{*}{\multicolumn{2}{|c|}{$\begin{array}{c}\text { PARENTAL } \\
\text { COMBINATIONS }\end{array}$}} & \multicolumn{6}{|c|}{ RECOMBINATIONS } & \multirow{2}{*}{ TOTAL } & \multicolumn{3}{|c|}{$\begin{array}{c}\text { PERCENT } \\
\text { RECOMBINATION COIN- }\end{array}$} \\
\hline & & & REGIO & N I & REGIO & N 2 & REGION & $\mathrm{S} I, 2$ & & $\stackrel{\mathrm{I}}{c-w x}$ & $\stackrel{2}{w x-T}$ & \\
\hline$T_{\mathbf{I}}-9 \mathrm{a}$ & I 54 & I3o & $5^{\circ}$ & 45 & 36 & 7 & $\mathbf{I}$ & 4 & 427 & $23 \cdot 4$ & II .2 & .44 \\
\hline$T r-9 b$ & 99 & 68 & 34 & 30 & 76 & $5^{6}$ & 14 & 15 & 392 & 23.7 & $4 \mathrm{I} . \mathrm{I}$ & .76 \\
\hline$T_{\mathbf{I}}-9 c$ & 74 & 71 & 24 & 38 & 22 & I & 6 & I & 237 & $29 . I$ & I 2.7 & .80 \\
\hline $\mathbf{T}_{2-}-\mathrm{a}$ & 42 & 47 & I 5 & I9 & 27 & 20 & 9 & I 2 & IgI & 28.8 & $35 \cdot 6$ & I. .07 \\
\hline$T 2-9 b$ & $2 \mathrm{Ig}$ & 225 & 54 & 83 & 22 & 20 & 2 & 3 & 628 & 22.6 & $7 \cdot 5$ & .47 \\
\hline $3-9 a$ & I I 6 & 55 & 29 & 8 & 5 & 2 & - & $一$ & 215 & 17.2 & $3 \cdot 3$ & - \\
\hline $3^{-9 b}$ & 127 & I 48 & 45 & 50 & IO & I I & 3 & 3 & 397 & 25.4 & 6.8 & .87 \\
\hline $3^{-9 c}$ & $6_{5}$ & 65 & I 5 & 25 & I4 & 2 & - & I & I87 & $2 I .9$ & $9 . I$ & .27 \\
\hline $4^{-} 9^{a}$ & 76 & 68 & I 8 & 43 & 29 & 40 & 9 & I 4 & 297 & 28.3 & 31.0 & .88 \\
\hline $4^{-9 a}$ & 134 & I 23 & 46 & $5 \mathrm{I}$ & 24 & I6 & $I$ & 5 & 400 & $25 \cdot 7$ & I I 5 & $.5 \mathrm{I}$ \\
\hline $6-9 b$ & 238 & 220 & $4 \mathrm{I}$ & 62 & I 5 & 4 & - & 3 & $5^{83}$ & I8.2 & 3.8 & .75 \\
\hline $8-9 b$ & $3 I$ & $3 I$ & 9 & II & 25 & I4 & 4 & 6 & $\mathbf{I 3 I}$ & 22.9 & $37 \cdot 4$ & .89 \\
\hline 9-1ob & I 75 & 126 & 67 & 77 & I4 & I 2 & I & 一 & 472 & 30.7 & $5 \cdot 7$ & .12 \\
\hline
\end{tabular}

chlorophyll gene in some of the $c w x$ stocks used. Under somewhat unfavorable weather conditions these proved practically lethal. While theoretically a lethal gene should not alter the linkage percentages, data in-

TABLE 2

Backcross progenies from combinations $\frac{C++T}{+s h w x+}$.

\begin{tabular}{|c|c|c|c|c|c|c|c|c|c|c|c|c|c|c|c|}
\hline & \multirow{2}{*}{\multicolumn{2}{|c|}{$\begin{array}{c}\text { PARENTAL } \\
\text { COMBINA- } \\
\text { TIONS }\end{array}$}} & \multicolumn{12}{|c|}{ RECOMBINATIONS } & \multirow[b]{2}{*}{ TOTAL } \\
\hline & & & \multicolumn{2}{|c|}{ REGION $\mathrm{r}$} & \multicolumn{2}{|c|}{ REGTON 2} & \multicolumn{2}{|c|}{ REGION 3} & I AND 2 & \multicolumn{2}{|c|}{ I AND 3} & \multicolumn{2}{|c|}{2 AND 3} & $\begin{array}{c}\mathrm{I}, 2 \\
\text { AND } 3\end{array}$ & \\
\hline T r $-9 \mathrm{~b}$ & 132 & 69 & 2 & 7 & 25 & 25 & 66 & 49 & & 2 & 2 & 9 & 8 & $\mathbf{I}$ & 397 \\
\hline$I-9 c$ & I 45 & $4 I$ & 3 & 3 & 28 & 29 & 24 & 5 & I & & & I & 3 & & 283 \\
\hline $2-9 a$ & 42 & 34 & 3 & I & I3 & $I_{5}$ & 19 & 6 & & & & 3 & 3 & - & I39 \\
\hline $4-9 a$ & 57 & $2 I$ & $I$ & 2 & I 7 & I 5 & 8 & 2 & I & & & 2 & 3 & & 129 \\
\hline $4-9 b$ & 68 & 78 & 6 & I & I9 & I4 & I & 4 & $\mathbf{I}$ & & & I & & & 193 \\
\hline
\end{tabular}


TABLE 3

Backcross progenies from combinations $\frac{+T}{w+}$.

\begin{tabular}{rrrrrrr}
\hline & $\begin{array}{c}\text { PARENTAL } \\
\text { COMBINATIONS }\end{array}$ & RECOMBINATIONS & TOTAL & $\begin{array}{c}\text { PERCENT } \\
\text { RECOMBINATIONS }\end{array}$ \\
\hline 2-9a & 63 & 56 & $3 \mathbf{I}$ & 25 & $\mathbf{1 7 5}$ & 32.0 \\
$3-9 \mathrm{a}$ & 202 & $\mathbf{1 7 6}$ & 9 & 6 & $\mathbf{3 9 3}$ & 3.8 \\
$3-9 \mathrm{C}$ & 67 & 66 & 6 & 2 & $\mathbf{1 4 \mathbf { I }}$ & 5.7 \\
\hline
\end{tabular}

Backcross progeny from $\frac{C+T}{+w x+}$.

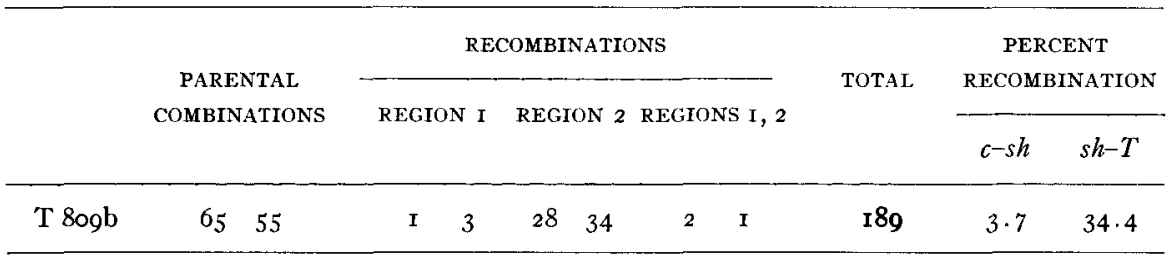

volving a lethal gene are not entirely trustworthy for accurate determinations. But for the approximations required in the present work, the data are probably accurate enough.

The T 4-9a progenies fall into two sharply different groups. Three cultures from a single plant, I I-3 I 5-2, gave I0.2, I 2.2, and I r.6 percent crossing over for the $w x-T$ interval. Two cultures from sibs of this plant gave 27. I and 34.9 percent for the same region. A closely related plant gave 27.6 percent. The two groups of data have been summarized separately. Cytological observations of one plant at mid-prophase of meiosis has shown the interchange of chromosomes about four fifths the way out on the long arm of 9 and very near the spindle attachment on 4 . This position would give an expectation of loose linkage corresponding to the higher crossover value. The low value obtained in cultures from I I-3 I $5^{-2}$ might be due to the presence of some other chromosomal alteration such as the short inversion about the spindle attachment of chromosome 4 which is known to be present in some stocks (MCCLINTOCK I933).

Some further data have been obtained on $\mathrm{T}$ 6-9a. Two sister $\mathrm{F}_{1}$ plants were backcrossed reciprocally with a $c w x$ stock. The data are given in table 5. With such small numbers of plants involved, not much reliance can be placed on these data. There is a marked difference in the crossover values when the plants are used as female or male, but the difference is opposite to that previously found for the $T-Y-P l$ region of chromosome 6 (ANDERSON I934). Obviously the crossing-over behavior of T 6-9a needs to be checked more carefully. 
TABLE 5

Reciprocal backcrosses of T 6-ga. Parental formula $\frac{C+T}{+w x+}$.

\begin{tabular}{|c|c|c|c|c|c|c|c|c|c|c|c|c|}
\hline \multirow{4}{*}{$\frac{\text { F }_{1} \text { PARENT }}{\text { II-3I8-I }}$} & \multirow{4}{*}{$\begin{array}{c}F_{1} \\
\text { USED } \\
\text { AS } \\
P\end{array}$} & \multirow{3}{*}{\multicolumn{2}{|c|}{$\begin{array}{l}\text { PARENTAL } \\
\text { COMBINA- } \\
\text { TIONS }\end{array}$}} & \multicolumn{6}{|c|}{ RECOMBINATIONS } & \multirow{3}{*}{ TOTALS } & \multirow{2}{*}{\multicolumn{2}{|c|}{$\begin{array}{c}\text { PERCENT } \\
\text { CROSSING OVER }\end{array}$}} \\
\hline & & & & \multirow{2}{*}{\multicolumn{2}{|c|}{ REGION I }} & \multirow{2}{*}{\multicolumn{4}{|c|}{ REGION 2 REGIONS I, 2}} & & & \\
\hline & & & & & & & & & & & \multirow{2}{*}{$\frac{C-w x}{27 \cdot 1}$} & \multirow{2}{*}{$\frac{w x-T}{21.4}$} \\
\hline & & I 8 & 20 & 8 & 9 & 6 & 7 & 2 & 0 & 70 & & \\
\hline & $\sigma^{7}$ & 108 & 107 & 26 & 45 & 9 & 2 & $\mathbf{I}$ & 2 & 300 & $24 \cdot 7$ & $4 \cdot 7$ \\
\hline \multirow[t]{2}{*}{ II $-3 I^{8}-5$} & 우 & $5^{I}$ & $5^{2}$ & 35 & 24 & 4 & 9 & 5 & 3 & 183 & $3^{6.6}$ & II. 5 \\
\hline & $\sigma^{7}$ & 78 & I7 & I 2 & I 2 & 3 & 2 & 2 & I & 127 & 21.3 & 6.3 \\
\hline
\end{tabular}

\section{CYTOLOGY}

Cytological examinations have been made of aceto-carmine preparations at mid-prophase of meiosis. Measurements and estimates of position of the interchange of chromosomes have been made from camera lucida tracings of the clearest figures. The position of the interchange is recorded in tenths of the distance from the spindle attachment to the end of the arm. Thus 9 L.4 indicates chromosome 9 long arm four-tenths of distance from the spindle attachment. In general these placements are probably reliable to about .I or .2 of the length of the arm. Those near the end of the chromosome are somewhat less reliable. In some cases, notably $\mathrm{T}$ 5-9a (BURNHAM I 934a) and T 6-9b, there is much non-homologous pairing (McCuIntock 1933), which makes it difficult to determine the normal position of the interchange.

The three translocations T 8-9a, T6-9a, and T 5-9a have been described. The following have been examined cytologically:

\begin{tabular}{|c|c|c|}
\hline$T_{I-9 b}$ & I L . 6 & $9 \mathrm{~L} .5$ \\
\hline$T$ I-9c & I $S .6$ & $9 \mathrm{~L} .2+$ \\
\hline $\mathrm{T}$ 2-9a & $2 \mathrm{~S} .7$ & $9 \mathrm{~L} .6+$ \\
\hline$T$ 2-gb & $2 S . x$ & $9 \mathrm{~L} .2$ \\
\hline$T_{3-9 a}$ & - & $9 \mathrm{~L} . \mathrm{I}+$ \\
\hline$T_{3-9 c}$ & $3 \mathrm{~L} . \mathrm{I}$ & $9 \mathrm{~L} .2$ \\
\hline $\mathrm{T}_{4-9 \mathrm{a}}$ & $4 \mathrm{~L}$. I & $9 \mathrm{~L} .8$ \\
\hline$T_{4-9 b}$ & $4 \mathrm{~T} .6$ & $9 \mathrm{~L} .2$ \\
\hline T 8-gb & $8 \mathrm{~S} .2$ & $9 \mathrm{~L} .8$ \\
\hline T 9-Iob & $9 \mathrm{~L} \cdot 3$ & Io near s.a. \\
\hline
\end{tabular}

$\mathrm{T} \mathrm{r-9a}$ and $\mathrm{T} 3-9 \mathrm{~b}$ have not been studied. $\mathrm{T} 6-9 \mathrm{~b}$ shows much non-homologous pairing, but seems to have the interchange in the proximal part of the long arm of 9 .

The writer is indebted to Mrs. Gertrude G. Frandsen for most of the cytological preparations. 
RELATION OF POSITION OF INTERCHANGE TO LINKAGE WITH WAXY

TABLE 6

Comparison of position of interchange with map distance from waxy.

\begin{tabular}{|c|c|c|c|}
\hline & $\begin{array}{l}\text { CYTOLOGICAL } \\
\text { POSITION }\end{array}$ & $\begin{array}{l}\text { PERCENT CROSSING } \\
\text { OVER FROM } w x\end{array}$ & $\begin{array}{l}\text { NUMBER OF PLANTS } \\
\text { IN LINKAGE TESTS }\end{array}$ \\
\hline $\mathrm{T}_{5-9 \mathrm{a}}$ & S.I & 2.0 & (BURNHAM I934a) \\
\hline $3-9 a$ & L.It & 3.6 & 608 \\
\hline $4-9 b$ & L. . 2 & $3 \cdot I$ & 193 \\
\hline $6-9 b$ & & 3.8 & $5^{83}$ \\
\hline $3-9 b$ & & 6.8 & 397 \\
\hline $2-g b$ & L . 2 & $7 \cdot 5$ & 628 \\
\hline $3-9 c$ & L. 2 & 7.6 & 328 \\
\hline$I-9 \mathrm{C}$ & L. .2t & I $2 . I$ & 520 \\
\hline $9-$ Iob & L. $\cdot 3$ & $5 \cdot 7$ & 472 \\
\hline $6-9 a$ & L. $\cdot 3$ & $9 \cdot 4$ & 955 \\
\hline$I-9 \mathbf{a}$ & & I I. 2 & 427 \\
\hline $8-9 a$ & L. $\cdot 4$ & $\mathrm{x} 3 \cdot 7$ & (BURNHAM I934b) \\
\hline$I-9 b$ & L $\cdot 5$ & $37 \cdot 7$ & 789 \\
\hline $2-9 a$ & L. $.6+$ & 30.7 & 505 \\
\hline \multirow[t]{2}{*}{$4-9 a$} & L. .8 & 31.0 & 297 \\
\hline & & II. 5 & 529 \\
\hline $8-9 b$ & L .8 & $37 \cdot 4$ & I3I \\
\hline
\end{tabular}

Table 6 gives a list of the interchanges involving chromosome 9 arranged in approximate order of their position in the chromosome and of their crossover distance from waxy. The first column gives the observed position in chromosome 9. The second column gives the percent of crossing over from waxy. The third column gives the total number of backcross plants on which the crossover percentages are based, summarized from the preceding tables. The correlation between the cytological observations and the percentages of crossing over is very close, considering the probable amount of error in the cytological placements. The loose linkages shown by $\mathrm{T}$ r-9b, T2-9a, T 4-9a, and T 8-9b probably represent longer map distances, which can be studied more effectively when one or more helpful genes arè found in the distal part of chromosome 9.

\section{SUMMARY}

Data are presented on linkage relations with waxy for fourteen translocations involving the long arm of chromosome 9 .

The amount of crossing over with waxy is closely correlated with the cytological position of the interchange (table 6).

\section{LITERATURE CITED}

Anderson, E. G., I934 A chromosomal interchange in maize involving the attachment to the nucleolus. Amer. Nat. 68: 345-350.

I935 Chromosomal interchanges in maize. Genetics 20: 70-83. 
BEADLE, G. W., I932 The relation of crossing over to chromosome association in Zea-Euchlaena hybrids. Genetics I7: $481-501$.

Burnham, C. R., I930 Genetical and cytological studies of semisterility and related phenomena in maize. Proc. Nat. Acad. Sci. 16: 269-277.

1934a Chromosomal interchanges in maize: Reduction of crossing over and the association of non-homologous parts (abstract). Amer. Nat. 68: 8I-82.

I934b Cytogenetic studies of an interchange between chromosomes 8 and 9 in maize. Genetics I9: $430-447$.

Creighton, Harriet B., 1934 Three cases of deficiency in chromosome 9 of Zea mays. Proc. Nat. Acad. Sci, 20: i I I-r I5.

Creighton, H. B. And McCuntock, B., i93 I A correlation of cytological and genetical crossing over in Zea mays. Proc. Nat. Acad. Sci. 17: 492-497.

Emerson, R. A., Beadle, G. W., ANd Fraser, A. C., r935 A summary of linkage studies in maize. Cornell Univ. Agri. Exp. Sta. Memoir 180: $1-83$.

McClinTock, BARBARA, I930 A cytological demonstration of the location of an interchange between two non-homologous chromosomes of Zea mays. Proc. Nat. Acad. Sci. 16: 791-796. I93 The order of the genes $c$, sh and $w x$ in Zea mays with reference to a cytologically known point in the chromosome. Proc. Nat. Acad. Sci. I7: 485-49r.

I933 The association of non-homologous parts of chromosomes in the mid-prophase of meiosis in Zea mays. Z. Zellf. mikr. Anat. I9: I9I-237.

I934 The relation of a particular chromosomal element to the development of nucleoli in Zea mays. Z. Zellf. mikr. Anat. 21: 294-328. 